\title{
Research
}

\section{Forest Clearing Dynamics and the Expansion of Landholdings in Apuí, a Deforestation Hotspot on Brazil's Transamazon Highway}

\author{
$\underline{\text { Gabriel C. Carrero }}^{1}$ and $\underline{\text { Philip M. Fearnside }}^{2}$
}

\begin{abstract}
We present a local-scale case study in the Rio Juma Settlement Project (RJSP) in Apuí, a deforestation hotspot in the southern portion of Brazil's state of Amazonas. We analyze land accumulation and land use strategies of households with a view to elucidating how their strategies are shaping deforestation. More than $76 \%$ of the household sample was from southern Brazil, and around $72 \%$ of them migrated to older expansion frontiers before reaching Apuí. The percentage of properties with legal land titles was up to five times less while land accumulation was much greater than reported for other settlement projects in Brazil. Land use change followed different patterns depending on whether the lot had been obtained with $100 \%$ forest cover or with inherited land use. Regression-tree analysis showed that the size of the cattle herd and the total area of the property do not always explain the area deforested, nor is the size of the deforested area necessarily related to productive activities. Lack of income obtained from livestock indicated that at least $30 \%$ of the cases studied were related to the speculative nature of land acquisition and deforestation. Increasing consolidation of land in larger, more highly capitalized ranches indicates the potential for high rates of deforestation in the future, even when the profitability of livestock is questionable.
\end{abstract}

Key Words: Amazonia; cattle; colonization; deforestation; land speculation; land use change; livestock; LUCC; LULUCF; migration; rainforest; ranching; settlement projects

\section{INTRODUCTION}

Deforestation of tropical forests has direct impacts on global warming, the water cycle, and biological diversity. The causes of tropical deforestation vary tremendously among different countries and over time in any given location. Rather than a single key variable impacting forest cover change, multiple synergies between proximate causes and underlying driving forces best explain tropical forest cover losses worldwide (Geist and Lambin 2001, 2002). In Indonesia, for instance, deforestation forces were dominated by government-sponsored movement, i.e., transmigration, of small farmers (Fearnside 1997), followed by timber exploitation (Osgood 1994), and, most recently, oil palm plantations (Koh and Wilcove 2008, Koh and Ghazoul 2010). In Cameroon, roads are a key driver, their effect being more through bringing in migrants than through facilitating transformation of land-use practices from subsistence to market-based production for those who already inhabit the areas (Mertens and Lambin 2000). A household survey in southern
Cameroon revealed a shift in the importance of several drivers over time: deforestation increased following an economic downturn in 1986, with demographic factors, mainly migration, being the dominant force through 1991, followed in the 1991-1996 period by the market for plantains and the increasing wealth of households, with improved roads reducing the inhibiting effect of distance to markets (Mertens et al. 2000). In Brazilian Amazonia the relative importance of such factors as government subsidies to large ranches, land speculation, and small-farmer settlement have varied over time (Fearnside 2005). Differences in actors and spatial differences in physical and economic factors also result in intra-regional heterogeneity in deforestation patterns (Fearnside 1986a, Brondízio et al. 2002, Aguiar et al. 2007).

Lambin (1994, 1997) and Kaimowitz and Angelsen (1998) have reviewed over 150 economic models of tropical deforestation. They criticize crossnational studies for the poor quality of the data used, among other problems (see Fearnside 1996). They 
also emphasize the great variety of deforestation drivers in different places and the need for more research at the local level. Kaimowitz and Angelsen (1998:5) find that land markets are one of the "major doubts ... that can only be resolved by further research." They conclude that "research will probably be more productive if it concentrates on household and regional-level studies, instead of national and global studies." The present study contributes to filling this need for a deforestation hotspot in Brazil.

In Brazilian Amazonia, a combination of colonization and agricultural policies fostered inmigration of landless peasants and gave heavy subsidies for entrepreneurs to raise livestock (Mahar 1979, 1989). The largest deforested areas are in the "arc of deforestation," a crescent-shaped area along the southern and eastern edges of the Amazon forest. Initial settlement was often done by family farmers from southern and northeastern Brazil who were subsequently supplanted by large ranches (Fearnside 1986b, 1987). Recently, deforestation has expanded from the arc of deforestation toward the center of the Amazon (Laurance 2000, Fearnside and Graça 2006), mainly to the southern part of the state of Amazonas and southern Roraima (Sawyer 2001).

The movement of population means movement of investment, which is a crucial factor influencing household decisions. Settlements and gold-mining areas ("garimpos") function as "poles" that accrue intra-regional migration (Ozório de Almeida and Campari 1995, Campari 2002, Perz 2002). Settlement projects account for approximately $15 \%$ of the total deforestation in Brazilian Amazonia (Brandão and Souza 2006). The trend of households continuously amassing land on expansion frontiers (Hecht 1993, Campari 2002) suggests that actors play different roles in landscape change over time. Ranching operations in settlement areas continually incorporate additional land, usually through purchase of adjacent properties to form a contiguous holding (Aldrich et al. 2006, Caldas et al. 2007).

The patterns of land use strategies in land accumulation on expansion frontiers are yet to be understood. However, information exists on the relationship between deforestation, land-holding, and cattle-herd sizes in such areas. Usually there is a positive correlation between property size and the number of cattle (Downing et al. 1992, Kaimowitz 1996, Ludewigs et al. 2009), as well as between the number of cattle and the availability of domestic credit (Moran 1981, Hecht 1993). The areas with the most fertile soils have more diversified production and are more resistant to lot turnover (Moran et al. 2005). Deforestation in areas with infertile soils and high rainfall asymptomatically declines in Amazonia in areas with annual precipitation levels above $1800 \mathrm{~mm}$, even in the presence of a road (Chomitz and Thomas 2001).

The speculative role of land that attracted entrepreneurs to Amazonia was important in the 1970 s and is still retained today to some degree (Fearnside 2008). This gives cattle a dynamic that might be partially independent of productivity (Hecht et al. 1988), which strongly shaped the landscape and the accumulation of land in the state of Rondônia from 1973 to 1986 (see Mahar 1979, 1989, Binswanger 1991). Although land speculation has been less profitable since inflation was reduced by the 1994 "Plano Real" economic reforms, cattle ranching for beef production is not always profitable on expansion frontiers. In general, annual rates of return in the Amazon vary between 3 and 15\% (Schneider et al. 2000, Arima et al. 2005). However, negative rates of return have been reported in Apuí if revenues from cattle alone are considered without the added value of logging and the appreciation of land values (Razera 2005).

Extensive pasture expansion in Apuí still occurs even in an area where economic returns are constrained by excessive rainfall and low soil fertility, among other characteristics. The Apuí deforestation hotspot offers the opportunity of, at the same time, analyzing the temporal dynamics of deforestation, the agents and socioeconomic factors specific to the region, and factors that are general for the Amazon as a whole. These factors include the past movements of the actors through a succession of agricultural-expansion frontiers before reaching Apuí, their strategies for generating income, and the way they contribute to shaping land cover on this frontier. We looked for evidence based on household land use that could elucidate how their strategies are shaping deforestation, considering the underlying forces in Apuí. We opted to use an approach that can represent patterns of household land use and land accumulation related to deforestation. Our hypothesis is that land accumulation and the expansion of pastures using investments from outside are driving deforestation in Apuí. The paper seeks to address the question of the relative importance of different factors in 
driving deforestation in Apuí, including household characteristics and land speculation.

\section{METHODS}

\section{Study Area}

The study area comprises the Rio Juma Settlement Project (RJSP), together with some neighboring properties in the municipality of Apuí, which is located in southeastern Amazonas $\left(7.20^{\circ} \mathrm{S}\right.$. Latitude, $59.89^{\circ} \mathrm{W}$. Longitude) along a $110-\mathrm{km}$ stretch of the Transamazon Highway (BR-230; Fig. 1). This highway connects Apuí with the city Humaita on the Madeira River $400 \mathrm{~km}$ to the west and with the town of Jacareacanga on the Tapajós River in the state of Pará $300 \mathrm{~km}$ to the east. The AM-174 Highway connects Apuí with Novo Aripuanã $290 \mathrm{~km}$ to the north. The area's extensive network of rivers is only navigable during the flood season, or about six months out of the year (SDS 2009). The roads are almost impassible in the period of heavy rains (December to April), which makes it difficult and costly to transport the products of agriculture or ranching from rural properties either to the town of Apuí or to more distant markets.

The expansion of roads and agriculture began in the early 1970s when the Transamazon Highway was built. In 1982 the RJSP was created by the National Institute of Colonization and Agrarian Reform (INCRA). The town of Apuí is located inside the RJSP. The RJSP features a block of approximately 5240 lots with a total area of 444,000 ha (Fig. 1), including areas of remaining forests and properties that were titled prior to the creation of the RJSP. The study area is composed of 108 access roads ("estradas vincinais") with a total length of approximately $1200 \mathrm{~km}$ and with varying degrees of trafficability (INCRA 2006). There are also logging tracks ("carreadores") opened by the landowners or by loggers.

Apuí has an average elevation of $135 \mathrm{~m}$ above sea level with flat to moderately undulating relief (RADAMBRASIL 1978). Annual precipitation is between 2200 to $2800 \mathrm{~mm}$ and annual average temperature is $26^{\circ} \mathrm{C}$. The climate is classified as monsoon tropical (Köppen 1948). The predominant soil type is Latossolo Vermelho-Amarelo in the Brazilian classification, an Ultisol (Aber and Melillo 1991, EMBRAPA 2006).
Apuí has undergone a process of population growth associated with increasing deforestation and expansion of ranching. The population tripled from the early 1990s to 2007, when the total exceeded 17,000 inhabitants, while the percentages of urban $(41.6 \%)$ and rural $(58.4 \%)$ population remained practically constant over the 1991-2000 period (IBGE 2007). Approximately $90 \%$ of the productive area of Apuí is occupied by pasture (IDAM 2008). The cumulative area deforested between 1990 and 2009 increased by a factor of four, totaling 167,670 ha (INPE 2009) with a herd of 139,000 head (IBGE 2010). Apuí was the municipality with the highest annual deforestation in the state of Amazonas in 2008 and 2009, totaling 7100 and 6460 ha, respectively (INPE 2009).

\section{Data collection and analysis}

A random sample was drawn from the set of lots with deforestation in $2008(n=4023)$ and, within this set, sample lots were chosen for which the household occupants could be found (Carrero 2009). The sample was separated into eight cohorts representing periods of occupation of lots since the creation of the RJSP in 1982 . We considered the frequency of lots in each cohort $\left(n_{i}\right)$ in relation to the total number of lots, and drew proportionately from each cohort. The sample therefore attempts to represent the proportion of lots occupied in each period as well the spectrum of total area of landholdings among households. An interview was scheduled with the person responsible for the household owning the lot. We interviewed 83 households in 78 days of data collection in the second half of 2008. A semistructured questionnaire was adapted from one designed by the Anthropological Center for Training and Research on Global Environmental Change (Indiana University, Bloomington, Indiana, U.S.A.). We also made land use sketch maps following the method of D'Antona et al. (2008).

The interview contained information about origin and migration, accumulation of lots, economy and structure of the household, and about the characteristics of the infrastructure and land use of rural properties. The information collected allowed analysis of land possession and land use change in the lots, cattle-herd size, and household labor and income. For each household we accounted for all rural properties within the RJSP and any other properties located up to $115 \mathrm{~km}$ from the town of 
Fig. 1. Location of Apuí in the Amazon region; study area delimited by the perimeter of the lots of the Rio Juma Settlement Project (RJSP) and by lots with deforestation.

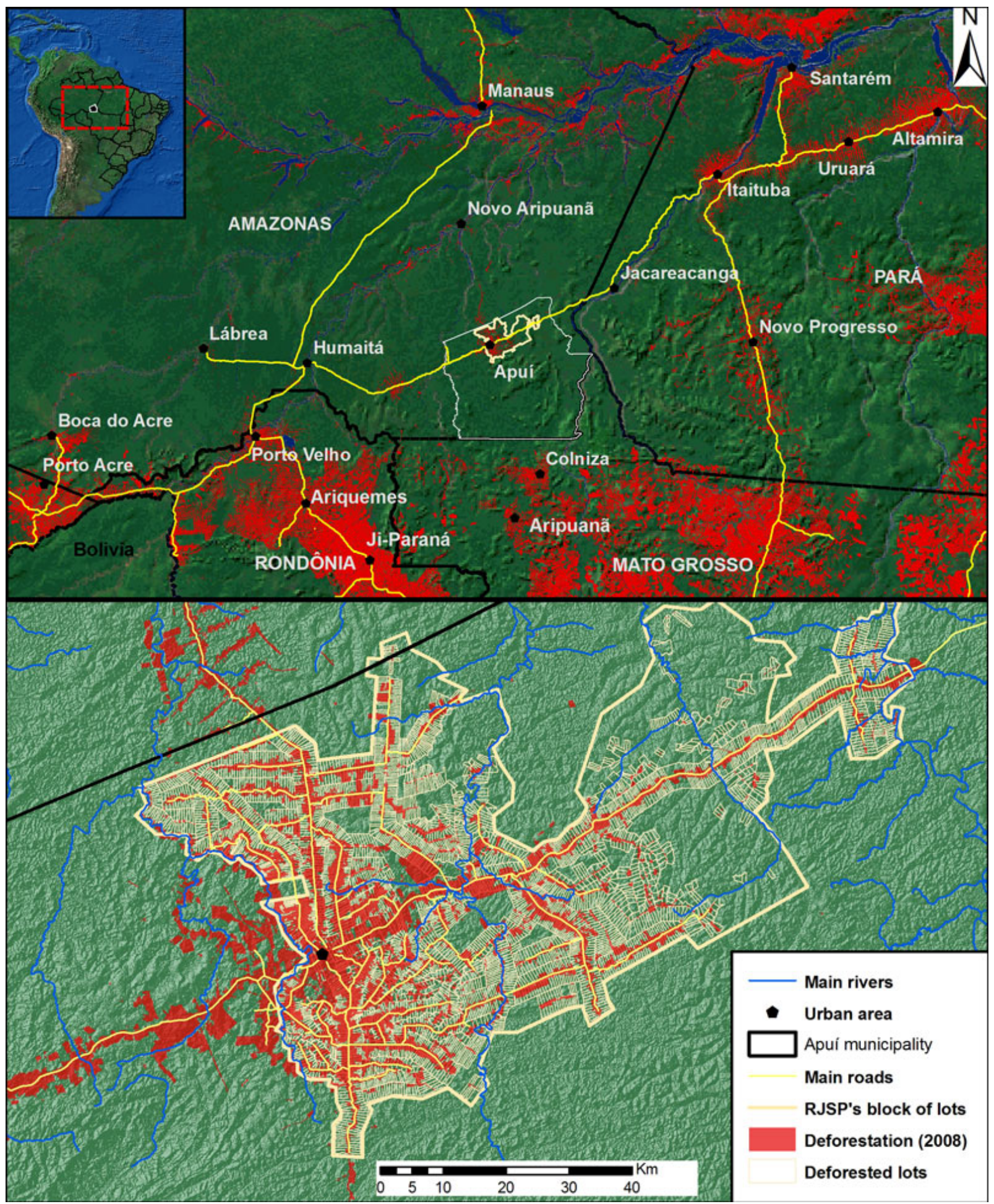


Apuí. This criterion was used to control for the effect of distance (transport) and for limitations on different responses regarding the productive use of properties by the household. The sample was composed of 83 households obtained from 83 randomly drawn lots. Note that some owners reside on their lots and earn income only from production, whereas others reside in the city and perform other economic activities, e.g., commerce, public office, etc., and vice versa. The effort to find the randomly drawn households is required if one is to represent the range of strategies of occupation and land accumulation, land use and consolidation.

We used regression-tree analysis (Breiman et al. 1984) considering a wide range of independent variables (Table 1). This method is suitable for exploring complex relationships among the data. The method accepts missing values and generates estimates of potential surrogate values for these (Therneau et al. 2009). The regression tree is constructed by continually dividing the sample based on a single dependent variable and also lists alternative or competitor variables for the chosen independent variable (De'ath and Fabricius 2000). We used the sum of squares about the group means, which is equivalent to least-squares linear models. We used the "I $-S E$ " rule to select the tree size by cross-validation, where " $S E$ " is the standard error (Breiman et al. 1984). This was done using the "mvpart" package in the $\mathrm{R}$ v. 2.6.2 statistical software platform ( $\mathrm{R}$ Core Development Team 2008).

We tested 20 variables that reflect household socioeconomic factors, with the total area deforested per household as the response variable. The response variable was transformed into $\log _{10}$ and had normal distribution (Shapiro-Wilk: $\log _{10} W$ $=0.98, p>0.47$ ). These values are presented in hectares when the leaves of the regression tree are shown.

Among the spatial variables are the place of residence, the geographical origin, the total area of properties, the remaining forest, and the proportion of areas of each land use: "dirty" pasture, "clean" pasture, felled areas, secondary vegetation, and crops (annual, perennial, or interplanted annual and perennial). To differentiate "dirty" pasture, i.e., pasture with invading woody secondary vegetation, from secondary vegetation, the respondents were first asked the total area of pasture and then asked to estimate the proportion in this area in the "clean" and "dirty" categories. The lot owner or manager was then asked about the area in secondary vegetation. The residence time since acquisition of the first property was used as a time variable. The physical variables were: the number of people who work in the properties as family labor, permanent labor, and daily labor, infrastructure for livestock, the number of head of cattle in the property and in the total holdings of the household. The livestock infrastructure was obtained from the sum of the number of corrals (weight 2), salt licks ("saleiros"; weight 1), troughs ("cochos"; weight 0.5 ) and pickets (weight 1). The "labor to outside" variable is the proportion of days of the year that members of the household worked for pay in third-party properties. Economic variables were: annual expenditure per person, i.e., food, health, education, transportation, clothing, leisure, etc., wealth, and principal activity.

\section{RESULTS}

\section{Migration, land tenure, and expansion of landholdings}

Approximately $77 \%$ of the households were from southern and southeastern Brazil $(43.9 \%$ and $32.9 \%$, respectively), while the remaining $23 \%$ were families from the center-west $(7.3 \%)$, northeast $(7.3 \%)$, and north $(8.5 \%)$ regions (Table $2)$. While 25 households (27.8\%) migrated directly to Apuí from their region of origin, $22(24.4 \%)$ first moved to the center-west region and then to Apuí. Before moving to Apuí, 37 families (41.1\%) resided in Rondônia and six (6.7\%) from the south region resided in Paraguay.

A total of 83 households were recorded in possession of 370 rural properties. Of these properties, 37 were deleted from the data set based on the cut-off threshold of $115 \mathrm{~km}$ from the center of Apuí. The average residence in Apuí was 16 years, and average total area possessed by the households was 345.5 ha, ranging between 25 and 4831 ha. The area of a family's holdings usually represents a set of adjacent lots in the RJSP (Fig. 2). The number of properties per household varied widely, with 17 having only one lot, 40 having two to five lot properties, 16 having six to ten properties, four families having between 11 and 20 properties and one household declaring itself as owning 38 adjacent lots, divided between grandfather, sons and daughters, and grandchildren (Fig. 3). There was no 
Table 1. Description of the variables used in the regression-tree analysis.

\begin{tabular}{|c|c|c|c|}
\hline Variable & Character $^{\dagger}$ & Type $^{\ddagger}$ & Values \\
\hline \multicolumn{4}{|l|}{ Dependent } \\
\hline Total deforestation $\left(\log _{10}\right)$ & $\mathrm{Sp}$ & $\mathrm{N}$ & $9.42-1300.00(0.45-3.11)$ \\
\hline \multicolumn{4}{|l|}{ Independent } \\
\hline Total area & $\mathrm{Sp}$ & $\mathrm{N}$ & $24.57-4831.02$ \\
\hline Residence & $\mathrm{Sp}$ & $\mathrm{C}$ & urban, rural \\
\hline Region of origin & $\mathrm{Sp}$ & $\mathrm{C}$ & center-west, south, east, north, northeast \\
\hline Pasture, "dirty" & $\mathrm{Sp}$ & $\mathrm{N}$ & $0-1$ \\
\hline Pasture "clean" & $\mathrm{Sp}$ & $\mathrm{N}$ & $0-1$ \\
\hline Secondary vegetation & $\mathrm{Sp}$ & $\mathrm{N}$ & $0-1$ \\
\hline Felled area & $\mathrm{Sp}$ & $\mathrm{N}$ & $0-0.83$ \\
\hline Crops (annual, perennial, and interplanted) & $\mathrm{Sp}$ & $\mathrm{N}$ & $0-0.52$ \\
\hline Remaining forest & $\mathrm{Sp}$ & $\mathrm{C}$ & $1(80-92 \%) ; 2,(50-80 \%), 3(20-50 \%), 4(<20 \%)$ \\
\hline Wealth class ${ }^{\S}$ & Ec & $\mathrm{C}$ & $(1,2,3$, and 4$)$ \\
\hline Annual expenditures & Ec & $\mathrm{N}$ & $\mathrm{R} \$ 240-19,320$ \\
\hline Principal activity & $\mathrm{Ec}$ & $\mathrm{C}$ & $\begin{array}{l}\text { Agriculture and ranching, commerce, urban } \\
\text { employment, unemployed }\end{array}$ \\
\hline Time of residence & Temp & $\mathrm{N}$ & $1-29$ \\
\hline Cattle (head per property) & Phys & $\mathrm{N}$ & $0-1600$ \\
\hline Cattle (head per family) & Phys & $\mathrm{N}$ & $0-1700$ \\
\hline Infrastructure for livestock & Phys & $\mathrm{N}$ & $0-61$ \\
\hline Family labor & Phys & $\mathrm{N}$ & $0-7$ \\
\hline Daily labor & Phys & $\mathrm{N}$ & $0-6$ \\
\hline Permanent labor & Phys & $\mathrm{N}$ & $0-6$ \\
\hline Labor to outside & Phys & $\mathrm{N}$ & $0-1$ \\
\hline
\end{tabular}

$\dagger$ Sp = spatial; Ec = cost-effective Phys = physical ; and Temp = temporal.

$¥ \mathrm{C}=$ categorical; $\mathrm{N}=$ numerical

$\S$ Wealth classes based on accumulated possessions: 1 - has no gas stove, refrigerator, or TV; 2 - has at least a gas stove, refrigerator, or TV; 3 - has vehicle (motorcycle, car, truck, or van) and at least one of the items above; and 4 - has two or more vehicles and at least one of the items above. 
Table 2. Characteristics of the household structure of the sample $(n=83)$ and their properties (a); origin and migration (b).

\begin{tabular}{|c|c|c|c|c|c|}
\hline \multicolumn{3}{|c|}{ Geographical origin } & \multicolumn{3}{|c|}{ Migration } \\
\hline & Frequency & $(\%)$ & & Frequency & $(\%)$ \\
\hline $\mathrm{CW}^{\dagger}$ & 6 & 7.3 & Origin>Apuí & 25 & 27.8 \\
\hline $\mathrm{NE}^{\ddagger}$ & 6 & 7.3 & Origin $>C W>$ Apuí & 22 & 24.4 \\
\hline $\mathrm{N}^{\S}$ & 7 & 8.5 & Origin>Rondônia>Apuí & 37 & 41.1 \\
\hline$S^{\prime}$ & 36 & 43.9 & S>Paraguay>Apuí & 6 & 6.7 \\
\hline $\mathrm{SE}^{\mathbb{I}}$ & 27 & 32.9 & & & \\
\hline
\end{tabular}

$\dagger$ Center-West (Distrito Federal, Goiás, Mato Grosso, Mato Grosso do Sul)

¥ Northeast (Alagoas, Bahia, Ceará, Maranhão, Piauí, Paraíba, Pernambuco, Rio Grande do Norte, Sergipe)

§ North (Acre, Amapá, Amazonas, Pará, Rondônia, Roraima, Tocantins)

| South (Paraná, Rio Grande do Sul, Santa Catarina)

II Southeast (Espírito Santo, Minas Gerais, Rio de Janeiro, São Paulo)

correlation between the number of properties or the total area and the number of persons in the household. Average household size was 3.6 persons, with a sex ratio of 1.36 men per woman.

In 338 properties out of $370(91.4 \%)$, members of the household were the self-declared owners. The other properties were usually owned by relatives who reside in Rondônia, in southern Brazil, or abroad, and who send money for the acquisition and consolidation of these properties. For $33.8 \%$ of the properties, the owners only had a bill of sale ("contrato de compra e venda"), which is not a document with legal validity; $30.1 \%$ of the properties had no document at all and only $16.0 \%$ of the properties had the name of a person in the household registered with INCRA. Only 10.3\% reported having a definitive title issued by INCRA and debts to the agency paid in full, $7.3 \%$ had definitive titles in the name of the previous owner together with a power of attorney signed in their favor, and $2.6 \%$ were in the process of "regularization." There had been a change of ownership in $77 \%$ of the properties. The average turnover since first occupation was 1.32 times per lot ( $n=310$ lots) for the properties studied, with a range from 0 to 6 .

A total of $70(84.3 \%)$ of the sampled households had cattle, with $97.5 \%$ of these having livestock on their lots. A total of 62 households $(75 \%)$ stated that cattle ranching was their main activity. However, approximately $30 \%$ of these declared that they do not get any income from this activity (Fig. 4). Although $68 \%$ of households reported themselves as being agricultural farmers before moving to Apuí, only $25(30.1 \%)$ grow agricultural products currently.

A total of $57 \%$ of households rented pastureland either to $(32 \%)$ or from $(33 \%)$ other settlers, while $8 \%$ do both. One household rented out pastureland and did not have cattle of their own. The larger local producers (> 1000 head) of livestock generally fatten cattle, whereas the smaller producers invest in breeding herds to produce calves for sale. None of the sampled households used inputs such as fertilizer or lime or performed any kind of preparation of the soil for their pasture. In $31 \%$ of cases at least one person in the household worked 
Fig. 2. The set of selected properties. Different colors represent each of the households.

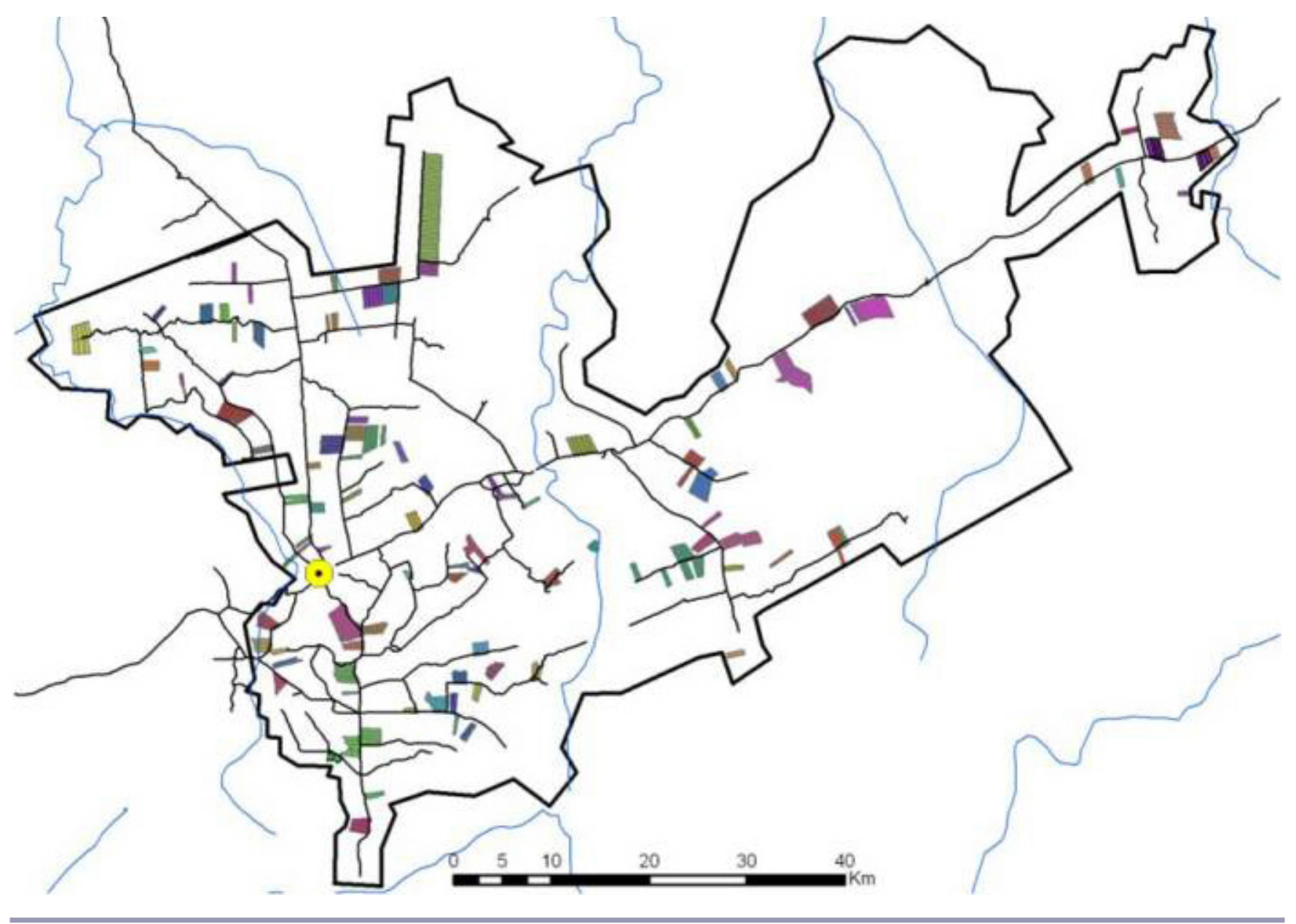

for other owners for daily pay, absorbing an average of $24 \%$ of the household's total yearly supply of rural labor. Of these hired household workers, $65 \%$ were hired to cut invading woody vegetation in pastures, $50 \%$ to build fences, and $19 \%$ to fell forest.

\section{Deforestation patterns and land use}

Properties can be separated into two types: those occupied/purchased with $100 \%$ forest cover and those that were already partially cleared when purchased, with the current owner therefore "inheriting" vegetation cover (Fig. 5). At the time of our survey, lots purchased with $100 \%$ forest cover had deforested area totaling $31.1 \%$, about evenly divided between "dirty" (14.3\%) and "clean" $(14.2 \%)$ pasture. Lots with inherited vegetation cover at the time of purchase had an average time of occupation by the current owner 2.2 years less than lots that were purchased with $100 \%$ forest. Lots with inherited land use underwent deforestation at a rate almost three times lower $(12.6 \%)$ than lots with $100 \%$ forest cover. Lots partially cleared before purchase contained a greater proportion of "dirty" pasture $(11.2 \%)$ than "clean" pasture $(8.3 \%)$, and a considerable proportion of secondary vegetation $(6.5 \%)$.

The regression tree explained $84.1 \%$ of the variation in the deforested area of households (Fig. 6). The size of the herd in the property defined the first division of the tree and explained $51.8 \%$ of the variation. The total area owned by the household was responsible for the second and third divisions. The second division added $13.1 \%$ to the explanation 
Fig. 3. Number of properties accumulated per household.

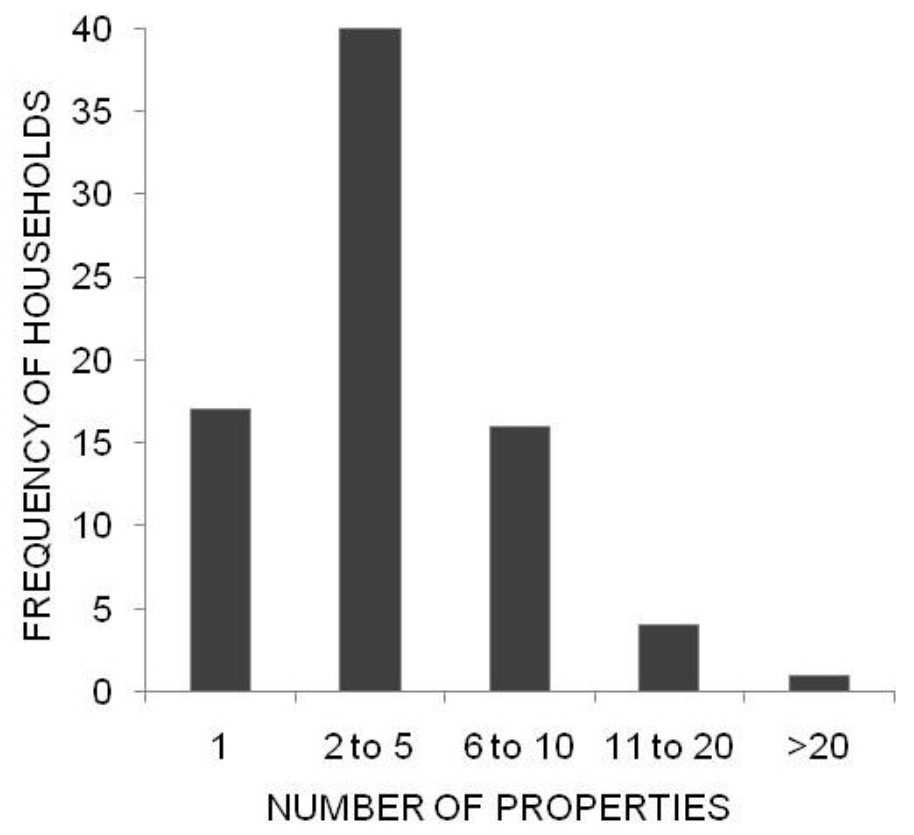

of deforestation, while the third division explained another $10.7 \%$. Cross-validation ensured the inclusion of the last two leaves of the tree, further reducing the error of the tree by $7.5 \%$. In the first three leaves of the tree, with less than 69 head of cattle, there were 16 households that had no cattle in their properties (Table 3). The average of 20.6 head of cattle in leaf 3 is lower than in leaf 2 (29.3 head). Leaf 4 shows almost the same deforested area as leaf 3 , but has three times as many cattle.

Where the variables were "total area" or "number of cattle in the property," the other variable served as an alternative split with an explanatory power of over $95 \%$, except in leaf 1 , where the number of cattle explained only $41 \%$ of the variation in the variable that had been selected ("total area"). Households in leaf 1 had considerable proportions of annual crops, secondary vegetation, and recently felled forest.

In summary, the results show that cattle are intimately tied both to the amount of deforestation and to the expansion of a household's holdings. At the same time, the low or nonexistent income from beef sales raises the questions of why Apuí is a deforestation hotspot and why cattle play such a central role.

\section{DISCUSSION}

\section{Migration and population origin}

The predominance of migrants from the south and southeast regions of Brazil shows that preferences and attitudes differed with respect to land accumulation. Unlike the migrants predominantly from Maranhão on frontiers in southern Pará (Fearnside 2001) and in southern Roraima, migrants from southern Brazil seem to be directed more toward economic growth, usually associated with prior experiences with credit and initial capital (Moran 1981). These differences in behavior patterns are relevant in light of the land concentration in Apuí as compared with other locations in Amazonia. Of Brazil's 1393 municipalities with positive net rates of migration and of employment creation over the 1995-2000 period (Matos 2007), Apuí ranks as the 34th and is one of the regions to which families who had settled in Rondônia have migrated. Another source of deforestation is capitalized ranchers who migrated directly from southern Brazil and from Paraguay between 1999 and 2005. We recorded 58 families who came to Apuí after living in Paraguay. Recently, there has been migration of landless 
Fig. 4. Percentage of income of the households that have ranching as their main activity $(n=62)$.

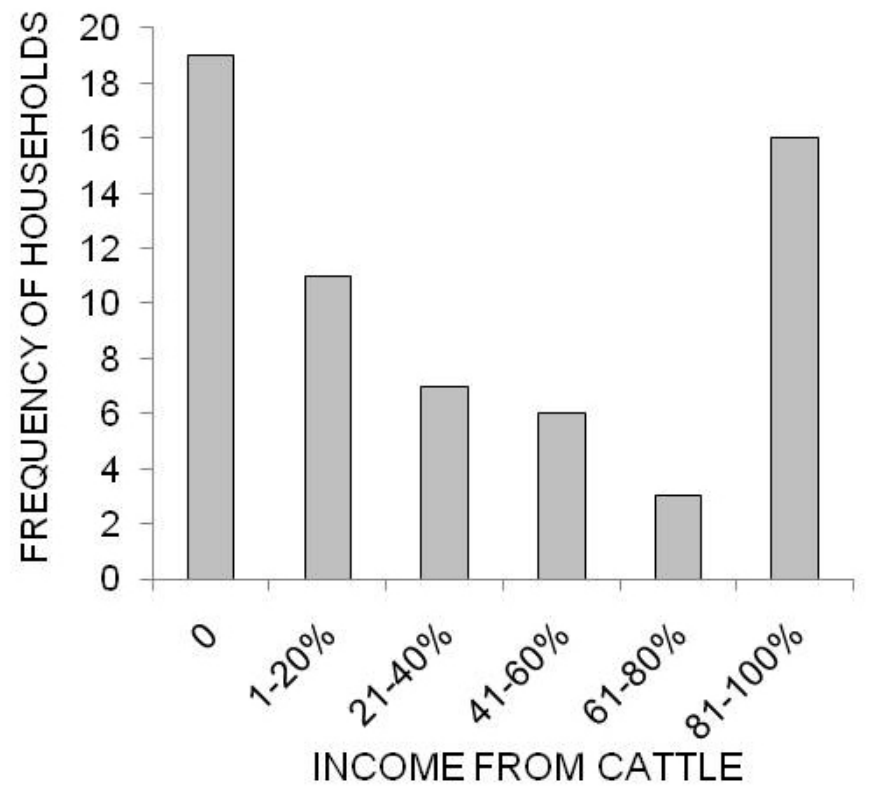

farmers coming from neighboring areas such as the municipality of Colniza in Mato Grosso and the municipality of Novo Progresso in southern Pará. These landless farmers can either be on their own or working for capitalized farmers to open land. Apuí's old occupants claim that these new migrants are responsible for most of the current deforestation.

\section{Household structure}

The average number of persons and the sex composition of the sampled households corroborate more detailed studies on the influence of family structure on deforestation and land use on Amazonian frontiers (Walker and Homma 1996, Marquette 1998, McCracken et al. 1999, 2002, Perz 2001). The average of 3.6 persons per household found in this study is low compared with 6.6 found by Marquette (1998) and 7.3 by Perz (2001) for Ecuadorian Amazonia and for Uruará in the Brazilian state of Pará, respectively. Nevertheless, these studies did not find household composition to have a significant effect on land cover change (see VanWey et al. 2007). The importance of the number of persons per household appears to diminish when households are using paid labor for felling. Even so, ranching is dependent on male labor (Marquette 1998, Perz 2001), with the number of adult men usually positively correlated with the area deforested (e.g., Godoy et al. 1998, SydenstrickerNeto 2004), a fact corroborated by the average sex ratio of 1.36 .

\section{Land tenure and accumulation}

Many properties in Apuí are untitled for a variety of reasons, in part because of INCRA's limited capacity for regional oversight in inspecting and issuing land titles. Ludewigs et al. (2009) found 93.6\% of settlement properties titled in Porto Acre (Acre), 53.2\% in Santarém (Pará), and 69.9\% in Altamira (Pará); these percentages are three to five times larger than the percentage in Apuí (17.6\%). Reasons for the low percentage of titling in Apuí include inability to pay the annual installments required for purchase of the lot; lot turnover that blocks the issuance of land titles because of mortgage debts; and land claimers who are ineligible to legally own another lot.

Land turnover can occur even in the absence of land titling because sales are made of the "right of 
Fig. 5. Percentages of vegetation-cover types in the properties of 83 households $(n=325)$ for two points in time ( $1=$ at the time of acquisition or occupation of the property, $2=$ in 2008) grouped into two classes: (a) properties occupied with $100 \%$ forest cover (average time of ownership $=8.83$ years $[ \pm 6.57]$ ); (b) properties that had been partially cleared when acquired from previous owners (average time of ownership $=6.66$ years $[ \pm 5.65])$.

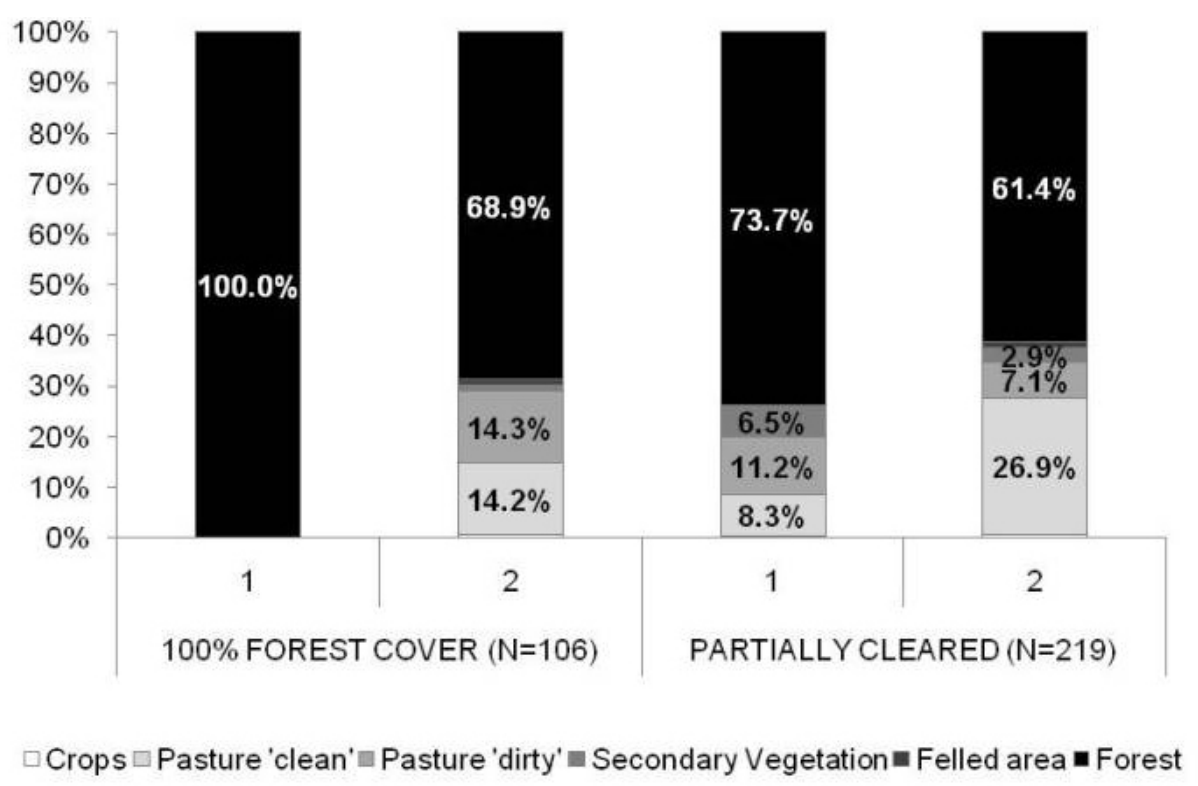

possession" ("direito da posse"), theoretically compensating the seller for "improvements" ("benfeitorias"). The frequent absence of land titles favors lot turnover and land accumulation. In the settlement in Uruará (Pará) in 1996, $18.9 \%$ of households $(n=132)$ had more than one lot with the maximum observed being five lots (Caldas et al. 2007). In the same settlement in 2002, Aldrich et al. (2006) found that $27.6 \%(n=125)$ had more than two lots, with the largest owner having seven lots. In our sample in Apuí $(n=78) 78.2 \%$ of the households owned two or more lots, with $27 \%$ (21 households) owning six or more lots. The lot turnover in Apuí was 77\%, a percentage similar to that in settlement areas in Porto Acre $(65 \%)$, Santarém (74\%), and Altamira (76\%), although the average total area per household in Apuí was, respectively, 3.7, 2.5, and 1.6 times larger than the averages in these other settlements (Ludewigs et al. 2009).

The geographical isolation and abysmal conditions of access also result in a low frequency of environmental audits, and the inefficiency of services provided by government agencies renders sustainable forest management unviable. The closest offices of environmental agencies are in Humaitá (400 km by road) or in Manaus $(500 \mathrm{~km}$ in a straight line, but with no access by road). Apuí is a municipality located on the edge of the arc of deforestation and is in obvious need of greater governance.

\section{Land speculation and deforestation}

The size of the cattle herd and the total area of landholdings were the most significant variables explaining the proximate causes of deforestation. However, when we analyze land use and land cover characteristics of the landholdings for the groups generated by the regression-tree analysis, some patterns can uncover strategies that denote land speculation. The price of land rose rapidly in Apuí, with the arrival of capitalized farmers from Paraguay, Rondônia, and southern Brazil from 1995 onward, inflating the value of land (Portal Apuí 2008). The high rate of abandonment of lots 
Fig. 6. Regression tree with total deforestation in 2008 as the dependent variable. Values below the nodes represent the percentages of reduction of error, or how much of the variance of the data the division in question was able to explain. The values of the terminal leaves $(1,2,3,4,5$, and 6) represent the average area deforested and the number of sample units, respectively.

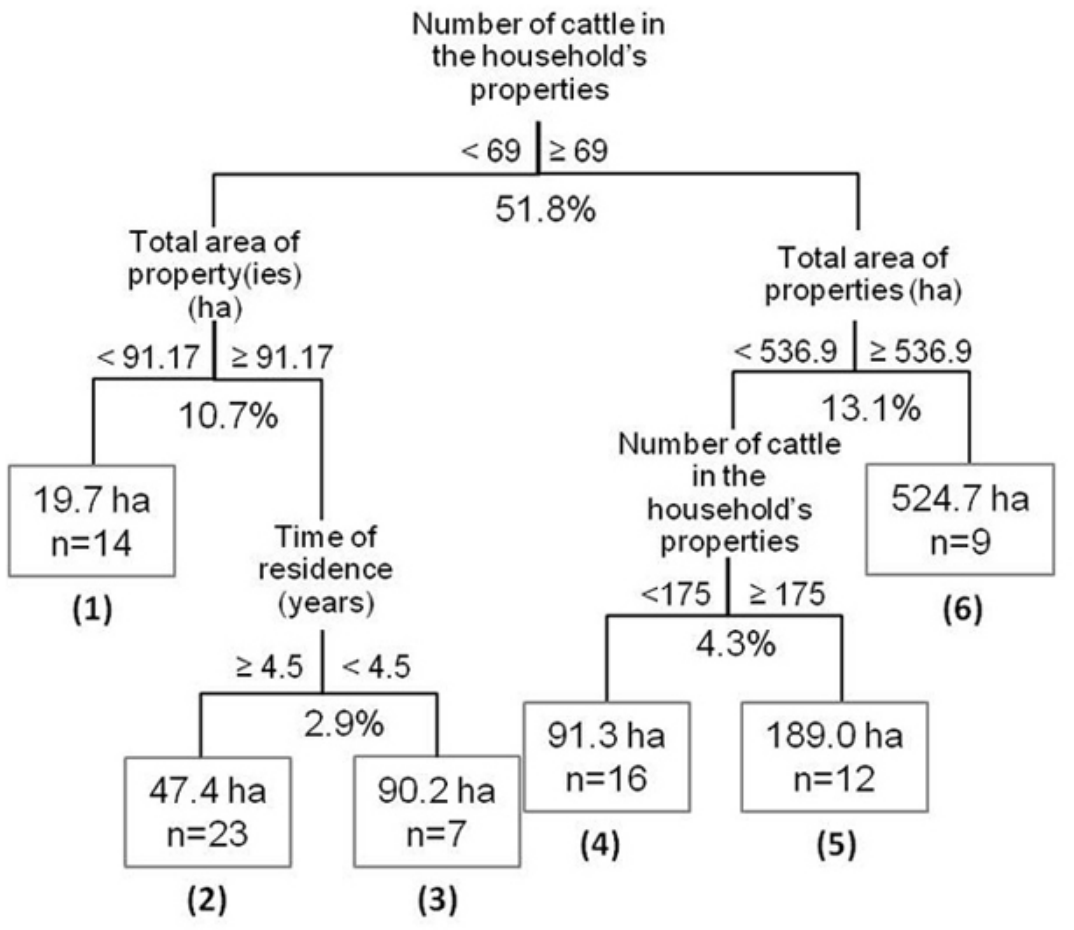

Error: 0.172 CV Error:0.389 SE:0.0495

contributed to land concentration as other settlers in the area acquired the land at token prices, or when these lots were bought by more highly capitalized newcomers. The value of timber contributes to speculation as well. Logging and sawmills have increased their contribution to the economy of the municipality; nine sawmills operated in 2010 compared with only four in 2004 (Razera 2005).

The ratio of livestock to the total area of pasture indicates that, although almost all settlers have livestock, in some cases this does not represent a significant source of income. Examination of results indicates that there is a tendency for the households not to rely exclusively on the profitability of ranching in their lots; instead, properties function as investment opportunities that drive land speculation. This fact was confirmed by $30.6 \%$ of households that had livestock as their main activity not obtaining any income from it. Capital coming from other sources is being invested in livestock and/or accumulation of land despite the lack of demonstrated profitability of livestock. The influx of capital for land purchases fuels the rise in land prices, creating a positive feedback between land speculation and deforestation that drives the expansion of pasture. This speculative cycle provides the explanation for what otherwise would be a true enigma: the expansion of pasture despite poor returns. Even though large-scale ranchers are known to bring external resources to support these activities (Walker et al. 2000), this trend was seen even in small and medium landholders in Apuí.

\section{Income generation and investment in forest destruction}

The accumulation of land based on the expansion of livestock in virgin forest appears to be driven by 
Table 3. Leaves formed by the regression-tree analysis of deforestation and mean values (standard deviation) of the variables acting as splits (bold).

\begin{tabular}{|c|c|c|c|c|c|c|}
\hline (Leaf) Splits & $\begin{array}{c}\text { Deforestation } \\
\text { (ha) }\end{array}$ & $n$ & \# Properties & \# Cattle & Total area (ha) & $\begin{array}{c}\text { Time of residence } \\
\text { (years) }\end{array}$ \\
\hline (1) $<69$ cat $\dagger,<91.2 \mathrm{ha} \ddagger$ & $19.7( \pm 8.1)$ & 14 & $1( \pm 0)$ & $4.4( \pm 6.6)$ & $66.9( \pm 18.5)$ & $6.4( \pm 4.2)$ \\
\hline (2) $<69$ cat, $\geq 91.2 \mathrm{ha}, \geq 4.5$ tper $^{\S}$ & $47.4( \pm 18.9)$ & 23 & $2.5( \pm 1.5)$ & $29.3( \pm 25.4)$ & $181.5( \pm 102.5)$ & $13.2( \pm 6.6)$ \\
\hline (3) $<69$ cat, $\geq 91.2 \mathrm{ha},<4.5$ tper & $90.2( \pm 37.4)$ & 7 & $3.43( \pm 1.3)$ & $20.6( \pm 25.0)$ & $244.7( \pm 126.1)$ & $2.7( \pm 0.9)$ \\
\hline (4) $\geq 69$ cat, $<536.9$ ha, $<\mathbf{1 7 5}$ cat & $91.3( \pm 30.4)$ & 16 & $3.56( \pm 2)$ & $110.6( \pm 32.5)$ & $247.8( \pm 147.9)$ & $14( \pm 8.4)$ \\
\hline (5) $\geq 69$ cat, $<536.9$ ha, $\geq 175$ cat & $189.0( \pm 59.0)$ & 12 & $5.0( \pm 1.5)$ & $335.7( \pm 106.2)$ & $363.1( \pm 85.0)$ & $8.9( \pm 7.3)$ \\
\hline (6) $\geq 69$ cat, $\geq 536.9$ ha & $524.7( \pm 368.0)$ & 9 & $13.3( \pm 10.1)$ & $485.22( \pm 477.4)$ & $1462.1( \pm 1362.9)$ & $13.3( \pm 6.4)$ \\
\hline
\end{tabular}

$\uparrow$ Number of cattle owned

\$Total area in possession of the household

$\S$ Time of residence (years) since the first property was purchased

external resources, even when the households have endogenous activities or supply labor to other properties. In addition to selling wood (Razera 2005), women, in particular, can bring money from urban sources to the household, which is invested in property (Marquette 1998, VanWey et al. 2007). The municipality of Apuí ranked 22nd of Brazil's 5507 municipalities at the time of the 2000 census in terms of the rate of increase in formal employment, i.e., employment under the aegis of government labor laws, over the $1995-2000$ period (Matos 2007). Gold prospecting has also been reported as a source of income for investment in agriculture and ranching activities in Apuí, as has also been the case in other settlement areas (MacMillan 1995, Phillips 2007).

The cutting of secondary vegetation contributes to reducing the rate of deforestation by absorbing the financial resources of newcomers for a while. However, high rates of deforestation continue to occur and will probably increase when secondary forest areas are significantly reduced and only oldgrowth forest remains available for clearing in the property, assuming that external capital and labor are available (Walker et al. 2000). In monthly monitoring of large increments in clearings ( $>25$ ha) using 250-m resolution MODIS imagery, the RJSP figured seven times among the three settlements with the highest deforestation rates in all of Brazilian Amazonia between May 2008 and May 2010, and was twice the "champion" in the first position, with rates up to 2500 ha in a single month (Souza et al. 2009, Hayashi et al. 2010). The predominant land use in Apuí is extensive animal husbandry based on expansion of pasture areas, with the expectation that the land will gain value. The result is the continued spread of destructive activity in the forest, even during a period when total deforestation rates in the Amazon have been declining (INPE 2009).

Efforts to arrive at global generalizations for deforestation causes often fall wide of the mark when one looks at a specific case. For example, the view of most tropical deforestation being caused by poor "shifted cultivators" (Myers 1980, 1994) does not fit well in Brazil, where most deforestation is the work of wealthier ranchers (Fearnside 2005). Within Brazilian Amazonia, the eastern portion of the region has ranching that is at least moderately profitable for beef production in areas with adequate road access (Mattos and Uhl 1994, Mertens et al. 2002, Margulis 2004), providing economic drivers 
in addition to those identified in our study in Apuí. Even in a relatively limited area, such as the municipality of Apuí $\left(54,251 \mathrm{~km}^{2}\right.$, an area larger than Costa Rica), different actors will behave in different ways.

\section{CONCLUSION}

The dominant source of migration to Apuí is movement of families of southern and southeastern Brazilian heritage who have lived in older expansion frontiers in the center-west or northern regions. The low level of land titling and weak governance appear to be major factors contributing to the land accumulation that has occurred faster in Apuí than in other settlement areas. Livestock facilitates the accumulation of land and its consolidation into larger ranches. Land use and clearing behavior depend on the land cover present when a property is purchased. Purchase of lots and the expansion and consolidation of livestock in Apuí do not seem to be linked to their profitability as cattle ranches, but instead are linked to investment from other sources. Settlement projects may serve as investment opportunities for funds from others sources. Lack of income from livestock indicated the speculative nature of land acquisition and deforestation in at least $30 \%$ of the ranchers studied.

The growing consolidation of land in larger and more capital-intensive properties indicates the potential for high rates of deforestation in the future. These findings also indicate the displacement of small farmers to other frontiers and the continuation of deforestation in these areas. This complexity of relationships among the actors involved on deforestation frontiers needs to be represented in models of land use dynamics to project the future course of deforestation in the Brazilian Amazon.

Responses to this article can be read online at: http://www.ecologyandsociety.org/voll6/iss2/art26/ responses/

\section{Acknowledgments:}

The National Council for Scientific and Technological Development $(\mathrm{CNPq})$ provided a fellowship to the first author. Paulo, Ricardo, Camila, Haroldo, and Rogimário served as field assistants. We thank the State Bureau of Rural Production (SEPROR-AM: IDAM and CODESAV), the National Institute of Colonization and Agrarian Reform (INCRA), and over 100 inhabitants of Apuí for conversations and/or documents. The Amazonas Sustainable Foundation (FAS), the BECA program of the International Institute of Education of Brazil (IIEB) together with the Moore Foundation, the National Institute for Research in Amazonia (INPA) PPI. PRJ05.57), and CNPq (Proc. 575853/2008-5; 305880/2007-1; 573810/2008-7) provided financial support. We thank FAS for the loan of two motorcycles used during fieldwork. We thankIDAM, the State Secretariat of the Environment and Sustainable Development (SDS-AM), and the Institute for Conservation and Sustainable Development of Amazonas (IDESAM) for logistical support and information. Eduardo S. Brondizio shared his field questionnaire and Paulo M.L.A. Graça, Claudia S.M.N. Vitel, Eduardo S. Brondízio, Stephen G. Perz, two anonymous reviewers and two Ecology and Society editors provided valuable feedback.

\section{LITERATURE CITED}

Aber, J. D., and J. M. Melillo. 1991. Terrestrial ecosystems. Saunders, Philadelphia, Pennsylvania, USA.

Aguiar, A. P. D., G. Câmara, and M. I. S. Escada. 2007. Spatial statistical analysis of land-use determinants in the Brazilian Amazonia: exploring intra-regional heterogeneity. Ecological Modelling 209:169-188.

Aldrich, S. P., R. T. Walker, E. Y. Arima, and M. M. Caldas. 2006. Land-cover and land-use change in the Brazilian Amazon: smallholders, ranchers, and frontier stratification. Economic Geography 52 (3):265-288.

Arima, E., P. Barreto, and M. Brito. 2005. Pecuária na Amazônia: tendências e implicações para a conservação ambiental. Instituto do Homem e Meio Ambiente da Amazônia (IMAZON), Belém, Pará, Brazil.

Binswanger, H. 1991. Brazilian policies that encourage deforestation in the Amazon. World Development 19(7):821-829. 
Brandão, Jr., A., and C. Souza, Jr. 2006. Desmatamento nos assentamentos de reforma agrária na Amazônia. O Estado da Amazônia 7. Instituto do Homem e Meio Ambiente da Amazônia (IMAZON), Belém, Pará, Brazil.

Breiman, L., J. H. Friedman, R. A. Olshen, and C. G. Stone. 1984. Classification and regression trees. Wadsworth International Group, Belmont, California, USA.

Brondízio, E. S., S. D. McCracken, E. F. Moran, A. D. Siqueira, D. R. Nelson, and C. RodriguezPedraza. 2002. The colonist footprint: toward a conceptual framework of land use and deforestation trajectories among small farmers in the Amazonian frontier. Pages 133-161 in C. H. Wood and R. Porro, editors. Deforestation and land use in the Amazon. University Presses of Florida, Gainesville, Florida, USA.

Caldas, M. M., R. T. Walker, E. Arima, S. G. Perz, S. Aldrich, and C. Simmons. 2007. Theorizing land cover and land use change: the peasant economy of Amazonian deforestation. Annals of the Association of American Geographers 97(1):86-110.

Campari, J. S. 2002. Challenging the turnover hypothesis of Amazon deforestation: evidence from Colonization Projects in Brazil. Dissertation. University of Texas, Austin, Texas, USA.

Carrero, G. C. 2009. Dinâmica do desmatamento e consolidação de propriedades rurais na fronteira de expansão agropecuária no sudeste do Amazonas. Thesis. Instituto Nacional de Pesquisas da Amazônia, Manaus, Amazonas, Brazil.

Chomitz, K. M., and T. S. Thomas. 2001. Geographic patterns of land use and land intensity in the Brazilian Amazon. Development Research Group Working Paper, World Bank, Washington, D.C., USA. [online] URL: http://citeseerx.ist.psu.edu/ viewdoc/download?doi=10.1.1.16.9879\&rep=rep1\&type= pdf.

D'Antona, A. O., A. D. Cak, and L. K. VanWey. 2008. Collecting sketch maps to understand property land use and land cover in large surveys. Field Methods 20(1):66-84.

De'ath, G., and K. E. Fabricius. 2000. Classification and regression trees: a powerful yet simple technique for ecological data analysis. Ecology 81 (1):3178-3192.
Downing, T. E., S. B. Hecht, H. A. Pearson, and C. G. Downing. 1992. Development or destruction: the conversion of tropical forest to pasture in Latin America. Westview, Boulder, Colorado, USA.

Empresa Brasileira de Pesquisa Agropecuária (EMBRAPA). 2006. Sistema brasileiro de classificação de solos. $2^{\mathrm{a}}$ Ed. Centro Nacional de Pesquisas de Solos (CNPS). EMBRAPA Solos, Rio de Janeiro, Rio de Janeiro, Brazil.

Fearnside, P. M. 1986a. Spatial concentration of deforestation in the Brazilian Amazon. Ambio 15 (2):72-79.

Fearnside, P. M. 1986b. Human carrying capacity of the Brazilian rainforest. Columbia University Press, New York, New York, USA.

Fearnside, P. M. 1987. Causes of deforestation in the Brazilian Amazon. Pages 37-61 in R. F. Dickinson, editor. The geophysiology of Amazonia: vegetation and climate interactions. John Wiley \& Sons, New York, New York, USA.

Fearnside, P. M. 1996. The causes of tropical deforestation: edited by Katrina Brown and David W. Pearce. Global Environmental Change Part A 6 (3):251-253.

Fearnside, P. M. 1997. Transmigration in Indonesia: lessons from its environmental and social impacts. Environmental Management 21(4):553-570. doi: $10.1007 / \mathrm{s} 002679900049$

Fearnside, P. M. 2001. Land-tenure issues as factors in environmental destruction in Brazilian Amazonia: the case of southern Pará. World Development 29(8):1361-1372. doi: 10.1016/ S0305-750X(01)00039-0

Fearnside, P. M. 2005. Deforestation in Brazilian Amazonia: history, rates and consequences. Conservation Biology 19(3):680-688. doi: 10.1111/ j.1523-1739.2005.00697.x

Fearnside, P. M. 2008. The roles and movements of actors in the deforestation of Brazilian Amazonia. Ecology and Society 13(1): 23. [online] URL: http: //www.ecologyandsociety.org/vol13/iss1/art23/.

Fearnside, P. M., and P. M. L. A. Graça. 2006. BR-319: Brazil's Manaus-Porto Velho Highway and the potential impact of linking the arc of 
deforestation to central Amazonia. Environmental Management 38:705-716. doi: 10.1007/s00267-005-0295$\mathrm{y}$

Geist, H. J., and E. F. Lambin. 2001. What drives tropical deforestation? A meta-analysis of proximate causes and underlying sources of deforestation based on subnational scale case study evidence. LUCC Report Series $\mathrm{N}^{\circ} 4$, LUCC International Project Office, Department of Geography, University of Louvain, Louvain-la Neuve, Belgium.

Geist, H. J., and E. F. Lambin. 2002. Proximate causes and underlying driving forces of tropical deforestation. BioScience 52:143-150.

Godoy, R., S. Groff, and K. O’Neill. 1998. The role of education in neotropical deforestation: household evidence from Amerindians in Honduras. Human Ecology 26:649-675.

Hayashi, S., C. Souza, Jr., M. Sales, and A. Veríssimo. 2010. Transparência Florestal Amazônia Legal (Abril e Maio de 2010). Instituto do Homem e Meio Ambiente da Amazônia (IMAZON), Belém, Pará, Brazil. [online] URL: http://www.imazon.org. $\mathrm{br} /$ publicacoes/transparencia-florestal/transparenciaflorestal-amazonia-legal/transparencia-florestal-daamazonia-legal-abril-e.

Hecht, S. B. 1993. The logic of livestock and deforestation in Amazonia. Bioscience 43 (3):687-695.

Hecht, S. B., R. B. Norgaard, and C. Possio. 1988. The economics of cattle ranching in eastern Amazonia. Interciencia 13:233-240.

Instituto Brasileiro de Geografia e Estatística (IBGE). 2007. Censos populacionais e agropecuários. IBGE, Rio de Janeiro, Rio de Janeiro, Brazil. [online] URL: http//:www.ibge.gov.br.

Instituto Brasileiro de Geografia e Estatística (IBGE) 2010. IBGE cidades: Apuí-AM. IBGE, Rio de Janeiro, Rio de Janeiro, Brazil. [online] URL: http://www.ibge.gov.br/cidadesat/topwindow.htm? 1 .

Instituto de Desenvolvimento Agropecuário (IDAM). 2008. Plano operativo anual Apuí- 2008. IDAM, Manaus, Amazonas, Brazil.
Instituto Nacional de Colonização e Reforma Agrária (INCRA). 2006. Levantamento da distribuição espacial das "ocupações" nos lotes dos Projetos de Assentamento Rio Juma e Acari. Superintendência Regional do Amazonas (SR-15), INCRA, Manaus, Amazonas, Brazil.

Instituto Nacional de Pesquisas Espaciais (INPE). 2009. Projeto Prodes: Monitoramento da floresta Amazônica Brasileira por satélite. INPE, São José dos Campos, São Paulo, Brazil. [online] URL: http ://www.obt.inpe.br/prodes/.

Kaimowitz, D. 1996. Livestock and deforestation: Central America in the 1980s and 1990s. A policy perspective. Center for International Forestry Research (CIFOR), Bogor, Indonesia.

Kaimowitz, D., and A. Angelsen. 1998. Economic models of deforestation. A review. Center for International Forestry Research (CIFOR), Bogor, Indonesia.

Koh, L. P., and J. Ghazoul. 2010. Spatially explicit scenario analysis for reconciling agricultural expansion, forest protection, and carbon conservation in Indonesia. Proceedings of the National Academy of Sciences 107:11140-11144.

Koh, L. P., and D. S. Wilcove. 2008. Is oil palm agriculture really destroying tropical biodiversity? Conservation Letters 1:60-64.

Köppen, W. 1948. Climatologia: con un estudio de los climas de la tierra. Fondo de Cultura Económica, Mexico City, Mexico.

Lambin, E. F. 1994. Modelling deforestation processes: a review. TREES series B: Research Report n1, European Commission, EUR 15744 EN. Office of Official Publications of the European Community, Luxembourg.

Lambin, E. F. 1997. Modelling and monitoring land-cover change processes in tropical regions. Progress in Physical Geography 21(3):375-393.

Laurance, W. F. 2000. Mega-development trends in the Amazon: Implications for global change. Environmental Monitoring and Assessment 61:113-122. 
Ludewigs, T., A. O. D'Antona, E. S. Brondízio, and S. Hetrick. 2009. Agrarian structure and land-cover change along the lifespan of three colonization areas in the Brazilian Amazon. World Development 37 (8):1348-1359.

MacMillan, G. 1995. At the end of the rainbow? Gold, land and people in the Brazilian Amazon. Columbia University Press, New York, New York, USA.

Mahar, D. J. 1979. Frontier development policy in Brazil: a study of Amazonia. Praeger, New York, New York, USA.

Mahar, D. J. 1989. Government policies and deforestation in Brazil's Amazon region. World Bank, Washington, D.C., USA.

Margulis, S. 2004. Causes of deforestation in the Brazilian Amazon. World Bank Working Paper No. 22. World Bank, Washington, D.C., USA.

Marquette, C. M. 1998. Land use patterns among small farmer settlers in the northeastern Ecuadorian Amazon. Human Ecology 26(4):573-598.

Matos, R. 2007. Novos espaços da migração ou espaços efêmeros do emprego e da população? $V$ encontro nacional sobre migrações. Universidade Estadual de Campinas (UNICAMP), Campinas, São Paulo, Brazil. [online] URL: http://www.abep. nepo.unicamp.br/docs/anais/outros/5EncNacSobreM igracao/mesa 01 nov esp mig.pdf.

Mattos, M. M., and C. Uhl. 1994. Economic and ecological perspective on ranching in the eastern Amazon. World Development 22(2):145-158.

McCracken, S. D., E. S. Brondízio, D. Nelson, E. F. Moran, A. D. Siqueira, and C. RodriguezPedraza. 1999. Remote sensing and GIS at farm property level: demography and deforestation in the Brazilian Amazon. Photogrammetric Engineering and Remote Sensing 65:1311-1320.

McCracken, S. D., A. D. Siqueira, E. F. Moran, and E. S. Brondízio. 2002. Land use patterns on an agricultural frontier in Brazil: insights and examples from a demographic perspective. Pages 162-192 in C. H. Wood and R. Porro, editors. Deforestation and land use in the Amazon. University Presses of Florida, Gainesville, Florida, USA.
Mertens, B., and E. F. Lambin. 2000. Land-cover change trajectories in southern Cameroon. Annals of the Association of American Geographers 90 (3):467-494.

Mertens, B., R. Poccard-Chapuis, M.-G. Piketty, A.-E. Laques, and A. Venturieri. 2002. Crossing spatial analyses and livestock economics to understand deforestation processes in the Brazilian Amazon: the case of São Felix do Xingu in South Pará. Agricultural Economics 27(3):269-294.

Mertens B., W. Sunderlin, O. Ndoye, and E. F. Lambin. 2000. Impact of macroeconomic transformations on deforestation in southern Cameroon: integration of household survey and remotely sensed data. World Development 28 (6):983-1000.

Moran, E. F. 1981. Developing the Amazon. Indiana University Press, Bloomington, Indiana, USA.

Moran, E. F., E. S. Brondízio, and L. K. VanWey. 2005. Population and environment in Amazônia: landscape and household dynamics. Pages 106-134 in B. Entwisle and P. C. Stern, editors. Population, land use, and environment: research directions. National Academy Press, Washington, D.C., USA. [online] URL: http://books.nap.edu/openbook.php? record $\mathrm{id}=11439 \&$ page $=106$.

Myers, N. 1980. Conversion of tropical moist forests. National Academy of Sciences, Washington, D.C., USA.

Myers, N. 1994. Tropical deforestation: rates and patterns. Pages 27-40. in K. Brown and D. W. Pearce, editors. The causes of tropical deforestation. The economic and statistical analysis of factors giving rise to the loss of the tropical forests. University College London Press, London, UK.

Osgood, D. 1994. Government failure and deforestation in Indonesia. Pages 217-225. in K. Brown and D. W. Pearce, editors. The causes of tropical deforestation. The economic and statistical analysis of factors giving rise to the loss of the tropical forests. University College London Press, London, UK.

Ozório de Almeida, A. L., and J. S. Campari. 1995. Sustainable settlement in the Brazilian Amazon. Oxford University Press, Oxford, UK. 
Perz, S. G. 2001. Household demographic factors as life cycle determinants of land use in the Amazon. Population Research and Policy Review 20:159-186.

Perz, S. G. 2002. Population growth and net migration in the Brazilian Legal Amazon, 1970-1996. Pages 107-129 in C. H. Wood and R. Porro, editors. Deforestation and land use in the Amazon. University Press of Florida, Gainesville, Florida, USA.

Phillips, T. 2007. Brazilian goldminers flock to "New Eldorado". The Guardian, 11 January. [online] URL: http://www.guardian.co.uk/world/2007/ jan/11/brazil.mainsection.

Portal Apuí. 2008. Nossa História. Portal Apuí, Apuí, Amazonas, Brazil. [online] URL: http://www. portalapui.com.br/index.php?option=com content\&view= article \&id=48\&Itemid $=3$.

R Core Development Team. 2008. R. version 2.6.2 (2008-02-08). The R Foundation for Statistical Computing, Auckland, New Zealand. [online] URL: http://www.r-project.org/.

RADAMBRASIL. 1978. Folha no. SB 20 Purus: geologia, pedologia, vegetação e uso potencial da terra. Departamento Nacional de Produção Mineral, Rio de Janeiro, Rio de Janeiro, Brazil.

Razera, A. 2005. Dinâmica do desmatamento em uma nova fronteira do sul do Amazonas: análise da pecuária de corte no Município do Apuí. Thesis. Instituto Nacional de Pesquisas da Amazônia (INPA) and Universidade Federal do Amazonas (UFAM), Manaus, Amazonas, Brazil.

Sawyer, D. 2001. Evolução demográfica, qualidade de vida e desmatamento na Amazônia. Pages 73-90 in V. Fleischresser, editor. Causas e dinâmica do desmatamento na Amazônia. Ministério do Meio Ambiente (MMA), Brasília, Distrito Federal, Brazil.

Schneider, R. R., E. Arima, A. Veríssimo, P. Barreto, and C. Souza, Jr. 2000. Amazônia sustentável: limitantes e oportunidades para o desenvolvimento rural. World Bank, Brasília, Distrito Federal, and Instituto do Homem e Ambiente na Amazônia (IMAZON), Belém, Pará, Brazil.

Secretaria de Meio Ambiente e Desenvolvimento Sustentável (SDS). 2009. Zoneamento ecológico econômico: diagnóstico do Município de Apuí. SDS, Manaus, Amazonas, Brazil.

Souza, Jr., C., A. Veríssimo, and S. Hayashi. 2009. Transparência florestal da Amazônia Legal (Julho de 2009). Instituto do Homem e Ambiente na Amazônia (IMAZON), Belém, Pará, Brazil. [online] URL: http://www.imazon.org.br/publicacoes/ transparencia-florestal/transparencia-florestal-amazonialegal/transparencia-florestal-da-amazonia-legal-julhode.

Sydenstricker-Neto, J. M. 2004. Land-cover change and social organization in Brazilian Amazonia. Dissertation. Cornell University, Ithaca, New York, USA.

Therneau, M. T., B. Atkinson, B. Ripley, J. Oksanen, and G. De'ath. 2009. 'Mvpart' Package, v. 1.2-6. The $\mathrm{R}$ Foundation for Statistical Computing, Auckland, New Zealand. [online] URL: http://cran.uvigo.es/web/packages/mvpart/mvpart. pdf.

VanWey, L. K., A. O. D'Antona, and E. S. Brondízio. 2007. Household demographic change and land use/land cover change in the Brazilian Amazon. Population and Environment 28:163-185.

Walker, R. T., and A. K. O. Homma. 1996. Land use and land cover dynamics in the Brazilian Amazon: an overview. Ecological Economics 18:67-80.

Walker, R. T., E. F. Moran, and L. Anselin. 2000. Deforestation and cattle ranching in the Brazilian Amazon: external capital and household processes. World Development 28(4):683-699. 